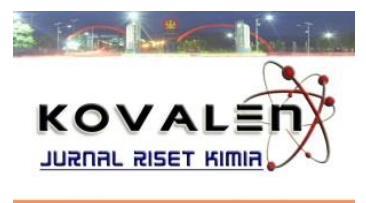

\title{
PEMANFAATAN GETAH BIDURI DALAM PRODUKSI ALBUMIN IKAN GABUS (Ophiocephalus striatus)
}

\section{[Utilization of Sap Biduri in The Production of Albumin Fish Cork (Ophiocephalus striatus)]}

\author{
Ita Mustrini $^{{ }^{\star *}}{ }^{\text {}}$, Mappiratu ${ }^{1)}$, Nurakhirawati ${ }^{1)}$ \\ 1) Jurusan Kimia FMIPA Universitas Tadulako, Palu \\ Jl. Soekarno Hatta Km.9, Kampus Bumi Tadulako Tondo Palu, Telp. 0451- 422611
}

Diterima 10 Mei 2016, Disetujui 1 Juli 2016

\begin{abstract}
The Research about utilization of sap Biduri in the production of albumin fish cork (Ophiocephalus striatus). Has been done This research purposes to determine the ratio of sap Biduri to extract cork fish that produce the protein albumin with the highest yield and optimum heating time which produces the highest yield of the protein albumin. The study used a completely randomized design (CRD), which consists of the influence of the ratio of sap Biduri to extract protein and the effect of heating time Biduri to extract latex mixture. Each treatment is done twice to obtain 22 units of the experiment. The highest protein yield was obtained at a ratio of sap Biduri $3,0: 30$ and the heating time of 60 minutes at $53,43 \%$. The purity of the highest degree obtained at the optimum 50 minutes warm up period of $35.50 \%$.
\end{abstract}

Keywords : Fish Cork, Biduri Protease enzyme, Protein yield of albumin, Albumin purity degree

\begin{abstract}
ABSTRAK
Telah dilakukan penelitian tentang pemanfaatan getah biduri dalam produksi albumin ikan gabus (Ophiocephalus striatus). Penelitian ini bertujuan untuk mengetahui rasio getah biduri terhadap ekstrak ikan gabus yang menghasilkan protein albumin dengan rendemen tertinggi dan waktu pemanasan optimum yang menghasilkan rendemen protein albumin tertinggi. Penelitian menggunakan rancangan acak lengkap (RAL) yang terdiri atas pengaruh rasio getah biduri terhadap ekstrak protein dan pengaruh waktu pemanasan campuran getah biduri dengan ekstrak. Setiap perlakuan dilakukan sebanyak dua kali sehingga diperoleh 22 satuan percobaan. Rendemen protein tertinggi diperoleh pada rasio getah biduri $3,0: 30$ dan waktu pemanasan 60 menit sebesar $53,43 \%$. Derajat Kemurnian tertinggi diperoleh pada waktu pemanasan optimum 50 menit sebesar 35,50\%.
\end{abstract}

Kata kunci: Ikan gabus, Enzim protease biduri, Rendemen protein albumin, Derajat kemurnian albumin. 


\section{LATAR BELAKANG}

Ikan Gabus termasuk kedalam hewan karnivora yang hidup didasar perairan, cenderung hidup dirawa, sungai dan perairan keruh. Ikan gabus merupakan salah satu ikan konsumsi yang populer dikalangan masyarakat Indonesia. Secara morfologi ikan gabus ini memiliki ciri yaitu bentuk badan yang bulat di depan dan pipih di belakang. Mempunyai punggung yang berwarna coklat tua hampir hitam dengan perut putih kecoklatan. Bagian punggung cembung, perut rata dan kepala pipih seperti ular. Ukuran maksimal ikan ini dapat mencapai 90 - $110 \mathrm{~cm}$ (Suprayitno, 2008).

Albumin merupakan jenis protein terbanyak didalam plasma yang mencapai kadar 60 persen dari total plasma atau sebanyak 4,5 g/dl. Kadar albumin normal dalam tubuh 3,5 - 4,5 g/dl, bila kurang dari 2,2 menunjukkan adanya masalah dalam tubuh (Carvallo, 1998). Kekurangan albumin dalam serum dapat mempengaruhi pengikatan dan pengangkutan senyawa - senyawa endogen dan eksogen, termasuk obat obatan karena diperkirakan distribusi obat keseluruh tubuh pengikatannya melalui fraksi albumin. Jika kadar albumin berada dibawah nilai normal, maka fraksi obat yang terikat protein tersebut berkurang, dengan kata lain fraksi obat bebas banyak sehingga keadaan ini dapat menimbulkan pengaruh obat yang tidak diinginkan (Tandra dkk, 1988).
Hasil penelitian sebelumnya oleh Suprayitno, dkk (2013), diketahui bahwa ikan gabus memilki kadar albumin yang tinggi, adapun cara ekstraksi untuk memperoleh albumin ikan gabus dari penelitiannya yaitu menggunakan metode pengendapan dengan ammonium sulfat yang dilanjutkan dengan pengeringan vakum. Metode lain yang juga dapat mengekstrak albumin dari ikan gabus adalah metode enzimatik. Enzim yang digunakan adalah enzim protease dari getah tanaman biduri (Calotropis gigantea). Menurut Witono (2007a, 2007b, 2007c), ekstrak protease tanaman biduri baik dari getah, batang, maupun dari daun sangat potensial sebagai sumber enzim protease. Biduri merupakan jenis tumbuhan semak liar tropis yang populasinya cukup melimpah, tumbuh pada lahan kering dan areal sekitar pantai. Protease sendiri merupakan enzim penghidrolisa protein yang banyak digunakan dalam industri pangan, seperti pembuatan keju, penjernih bir, pembuatan roti, pengempuk daging, hidrolisat protein, ekstraksi minyak dan sebagainya.

Pada Industri penyamakan kulit memanfaatkan enzim protease sebagai agensia bating (pengikis protein globular), didalam perdagangan dikenal dengan nama oropon atau enzylon. Menurut Poedjiadi (1994), albumin termasuk dalam golongan protein globular yang umumnya berbentuk bulat atau elips dan terdiri dari rantai polipeptida yang berlipat. Protein globular pada umumnya mempunyai sifat 
dapat larut dalam air, dalam larutan asam atau basa dan dalam etanol. Ditambahkan oleh De Man (1997), albumin juga mempunyai sifat dapat dikoagulasi dengan pemanasan. Enzim protease berguna untuk menggumpalkan protein yang salah satunya termasuk albumin, sehingga enzim protease berpeluang digunakan untuk mengekstrak protein albumin dari ikan gabus.

\section{METODE PENELITIAN}

\section{Bahan dan Peralatan}

Bahan dasar yang digunakan dalam penelitian ini adalah ikan gabus. Bahan bahan lain yang diperlukan yaitu getah tanaman biduri dan aquadest.

Peralatan yang digunakan antara lain: baskom, pisau, timbangan, neraca analitik, blender, gelas kimia $50 \mathrm{ml}$, erlenmeyer $250 \mathrm{ml}$, gelas ukur $100 \mathrm{ml}$, sentrifuge, tabung sentrifuge, labu ukur $25 \mathrm{ml}$, batang pengaduk, corong kaca, termometer, stopwatch, waterbath, kain saring, oven vakum, cawan petri, spektrofotometer Uv, dan kuvet.

\section{Prosedur Penelitian}

\section{Ekstraksi Protein Albumin lkan gabus (Askar, 2005)}

Ekstraksi protein albumin ikan gabus dilakukan dengan cara menimbang ikan gabus kemudian disiangi (dibuang sisik, isi perut, insang, sirip, kepala dan kulitnya). Ikan selanjutnya dipotong-potong kemudian dicuci hingga bersih dan daging dipisahkan dari tulang. Daging selanjutnya ditimbang kemudian ditambah aquadest dengan perbandingan 1: 5 (100 g : $500 \mathrm{ml})$ atas dasar berat / volume, dihancurkan dengan blender. Campuran disaring, filtrat (ekstrak) ditampung dan diukur volumenya, selanjutnya ditentukan kadar proteinnya.

\section{Pengendapan Protein dengan Getah Biduri}

Pengendapan protein secara enzimatik menggunakan getah biduri dilakukan melalui penerapan perlakuan pengaruh rasio getah biduri terhadap ekstrak protein dan pengaruh waktu pemanasan. Pada pengaruh rasio getah biduri terhadap ekstrak digunakan 5 tingkatan rasio masing-masing $1: 30 ; 1,5$ : $30 ; 2: 30 ; 2,5: 30 ; 3: 30$ atas dasar volume/volume. Pengaruh waktu pemanasan diterapkan 6 tingkatan waktu masing-masing 10, 20, 30, 40, 50 dan 60 menit. Parameter yang diamati adalah rendemen protein albumin dan derajat kemurnian albumin.

Ekstrak protein dengan jumlah tertentu dimasukkan kedalam gelas kimia $50 \mathrm{ml}$, kemudian ditambahkan getah biduri sesuai perlakuan. Campuran dipanaskan pada suhu $60^{\circ} \mathrm{C}$ selama 30 menit. Endapan yang terbentuk dipisahkan kemudian dikeringkan dan ditimbang untuk mengetahui beratnya. Perlakuan menghasilkan rendemen tertinggi digunakan untuk menentukan waktu pemanasan.

\section{Penetapan Kadar Protein Ekstrak}

Kadar protein ekstrak ikan gabus ditentukan menggunakan metode 
spektrofotometri. Ekstrak protein diencerkan jika perlu kemudian diukur serapannya pada panjang gelombang 260 $\mathrm{nm}$ dan $280 \mathrm{~nm}$. Kadar protein dihitung menggunakan persamaan berikut :

Kadar Protein $(\mathrm{mg} / \mathrm{ml})=\mathrm{A} 280 \times$ faktor koreksi $x$ pengenceran

Ket: (faktor koreksi = A280 / A260)

\section{Penetapan Derajat Kemurnian Ekstrak Albumin}

Protein albumin yang dihasilkan dilarutkan dengan $100 \mathrm{ml}$ aquadest. Larutan albumin selanjutnya disentrifuge pada 3000 rpm selama 1 jam. Supernatan yang dihasilkan diukur volumenya dan ditentukan kadarnya menggunakan metode UV pada panjang gelombang 260 $\mathrm{nm}$ dan $280 \mathrm{~nm}$. Kadar albumin dihitung menggunakan persamaan :

$\operatorname{Kadar}$ Albumin $(\mathrm{mg} / \mathrm{ml})=\mathrm{A} 280 \times$ faktor koreksi $x$ pengenceran

Ket: (faktor koreksi = A280 / A260)

Derajat Kemurnian $=\frac{\text { Berat Albumin }}{\text { Berat Protein }} \times 100 \%$

\section{HASIL DAN PEMBAHASAN}

Tahapan pertama yaitu ekstraksi protein albumin ikan gabus. Pada tahap ini ikan gabus terlebih dahulu ditimbang kemudian disiangi (dibuang sisik, insang, isi perut, sirip, kepala, dan kulitnya) setelah itu daging ikan gabus diblender dengan perbandingan $1: 5$ (100 gr daging ikan gabus : $500 \mathrm{ml}$ aquadest) atas dasar b/v. Tahapan ekstraksi ini merupakan metode kontrol. Berdasarkan hasil penelitan Askar (2005), secara keseluruhan konsentrat protein ikan gabus yang diolah dengan metode kontrol merupakan cara pengolahan yang paling baik dibandingkan dengan metode perebusan dan pengukusan karena ikan gabus langsung diekstrak tanpa pemanasan terlebih dahulu sehingga rendemen protein yang dihasilkan lebih tinggi.

Kemudian ekstrak yang dihasilkan diukur kadar proteinnya menggunakan spektrofotometer Uv pada $\lambda 260 \mathrm{~nm}$ dan $\lambda$ $280 \mathrm{~nm}$. Metode spektrofotometri Uv merupakan analisis kadar protein secara kuantitatif. Panjang gelombang maksimum spesifik untuk setiap sampel yang berfungsi mengurangi adanya interferensi serapan oleh molekul zat lain dalam suatu sampel (Day \& Underwood, 2001). Menurut Rohman (2007), Asam amino penyusun protein diantaranya adalah triptofan, tirosin, dan fenilalanin yang mempunyai gugus aromatik. Triptofan mempunyai absorpsi maksimum pada 280 $\mathrm{nm}$. Absorpsi sinar pada $280 \mathrm{~nm}$ dapat digunakan untuk estimasi konsentrasi protein dalam larutan. Supaya hasilnya lebih teliti perlu dikoreksi kemungkinan adanya asam nukleat dengan pengukuran absorpsi pada $260 \mathrm{~nm}$ untuk melihat kemungkinan kontaminasi asam nukleat. Rasio absorpsi 280/260 menentukan faktor koreksi yang ada dalam suatu tabel. Spektrofotometer UV memiliki panjang gelombang 190 - $380 \mathrm{~nm}$. Sebagai sumber sinar dapatdigunakan lampu deuterium karena sinar Uv tidak dapat dideteksi oleh mata, maka senyawa yang 
dapat menyerap sinar ini merupakan senyawa yang tidak memiliki warna, bening, dan transparan. Oleh karena itu sampel tidak berwarna tidak perlu dibuat berwarna dengan penambahan reagen tertentu. Bahkan sampel dapat langsung dianalisa meskipun tanpa preparasi. Namun sampel keruh tetap harus dibuat jernih dengan filtrasi atau sentrifugasi. Prinsip dasar spektrofotometri adalah sampel harus jernih dan larut sempurnah tidak ada koloid apalagi suspenssi (Riyadi, 2009). Dari hasil pengukuran kemudian dihitung kadar proteinnya yaitu $5,64 \mathrm{mg} / \mathrm{ml}$ dan berat protein $2818,62 \mathrm{mg}$.

Tahapan selanjutnya yaitu pengendapan protein dengan getah biduri. Pada tahap ini pengendapan protein dilakukan secara enzimatik atau hidrolisis protein menggunakan enzim protease getah biduri. Menurut Witono (2007d), melalui tehnik hidrolisis, protein suatu bahan dapat diubah menjadi senyawa asam amino $\mathrm{L}$, nukleotida,dan berbagai ragam peptida. Proses hidrolisis dapat dilakukan secara kimiawi maupun enzimatis. Proses hidrolisis kimiawi yaitu dengan penambahan asam klorida dapat memperpendek waktu pembuatan, mempermudah dan mengurangi biaya pembuatan. Namun demikian, dengan tehnik kimia produk protein yang dihasilkan kurang baik dan keamanan bagi kesehatan kurang terjamin. Hidrolisis secara enzimatik lebih menguntungkan secara kimiawi karena dapat menghasilkan asam - asam amino bebas dan peptide dengan rantai pendek yang bervariasi misalnya albumin.

Pada tahapan ini diterapkan 5 tingkatan rasio getah biduri yaitu $1,0: 30$; $1,5: 30 ; 2,0: 30 ; 2,5: 30 ;$ dan $3,0: 30$ atas dasar $\mathrm{v} / \mathrm{v}$ dan setiap perlakuan diulang sebanyak 2 kali pengulangan. Dari hasil perlakuan diperoleh berat endapan tertinggi yaitu pada penambahan getah biduri sebanyak $3 \mathrm{ml}$ pada waktu pemanasan 30 menit (Gambar 1).

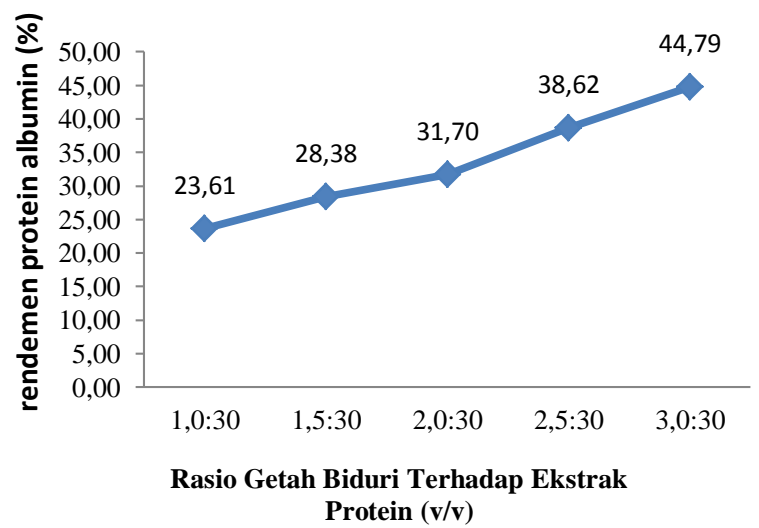

Gambar 1. Grafik hubungan antara rasio getah biduri terhadap ekstrak protein dengan rendemen protein albumin.

Dari Gambar 1 diketahui bahwa rendemen protein albumin tertinggi pada rasio $3,0: 30$ yaitu sebesar $44,79 \%$. Pada saat penambahan enzim protease biduri, ekstrak pada berbagai rasio getah biduri mulai mengalami penggumpalan (koagulasi) pada waktu 5 menit. Terjadinya penggumpalan disebabkan sifat dari enzim protease biduri yang dapat menggumpalkan protein dan memecah ikatan peptida menjadi ikatan-ikatan pendek. Adapun suhu pemanasan pada waterbath untuk semua perlakuan sama yaitu suhu $60^{\circ} \mathrm{C}$, digunakan suhu $60^{\circ} \mathrm{C}$ 
karena merupakan suhu optimum kerja enzim protease biduri berdasarkan hasil penelitian Witono (2002a dan 2002b). Setelah dipanaskan selama 30 menit kemudian disentrifuge $3000 \mathrm{rpm}$ selama 30 menit. Begitupula dengan suhu pengeringan oven pada semua perlakuan sama yaitu $50^{\circ} \mathrm{C}$. Dari gambar 1 diketahui bahwa rendemen protein terus meningkat seiring dengan rasio getah biduri yang semakin besar. Hal ini menunjukkan bahwa raasio getah biduri berpengaruh terhadap rendemen protein albumin.

Menurut Witono (2007d), semakin banyak konsentrasi enzim protease biduri yang ditambahkan dan semakin lama waktu hidrolisis, maka semakin banyak ikatan peptide dari protein yang terputus menjadi molekul yang lebih kecil. Hal ini karena enzim protease bersifat memecah protein menjadi peptide pendek dan asamasam amino yang mudah larut. Sehingga diketahui bahwa semakin besar rasio getah biduri maka semakin tinggi rendemen protein albuminnya. Sebagaimana dikatakan oleh Nielsen (1997) bahwa semakin besar konsentrasi protease akan semakin banyak ikatan peptida dari protein yang terputus menjadi peptida-peptida sederhana, sehingga kelarutan protein akan semakin meningkat.

Hasil ini dibuktikan dengan hasil uji statistik rendemen protein albumin ikan gabus yaitu nilai $F$ hitung 425,55 dan $F$ tabel 0,01 dan 0,05 yaitu 5,19 dan 11,39 sehingga nilai $F$ hitung $>F$ tabel 0,01 dan
0,05 (berbeda sangat nyata). Selain itu juga dibuktikan dengan hasil Uji BNJ taraf $1 \%$ rendemen protein albumin ikan gabus yang menunjukkan angka yang diikuti huruf yang sama pada kolom yang sama, hasilnya pada semua perlakuan 1,0:30, $1,5: 30,2,0: 30,2,5: 30$, dan $3,0: 30$ berbeda nyata. Jadi, rasio getah biduri yang menghasilkan rendemen protein albumin tertinggi yaitu pada rasio 3,0:30 dengan rendemen protein albumin sebesar $44,79 \%$.

Dari perlakuan sebelumnya diketahui bahwa rasio getah biduri $3,0: 30$ menghasilkan rendemen protein tertinggi. Sehingga untuk menentukan waktu pemanasan yang menghasilkan rendemen tertinggi digunakan rasio getah biduri 3,0 : 30 pada 6 tingkatan waktu pemanasan (10, 20, 30, 40, 50, dan 60 menit). Dimana parameter yang diamati pada perlakuan ini yaitu rendemen protein albumin dan derajat kemurnian albumin ikan gabus. Pada perlakuan ini dihasilkan berat endapan yang semakin besar serta rendemen protein yang semakin meningkat seiring dengan lamanya waktu pemanasan (waktu hidrolisis).

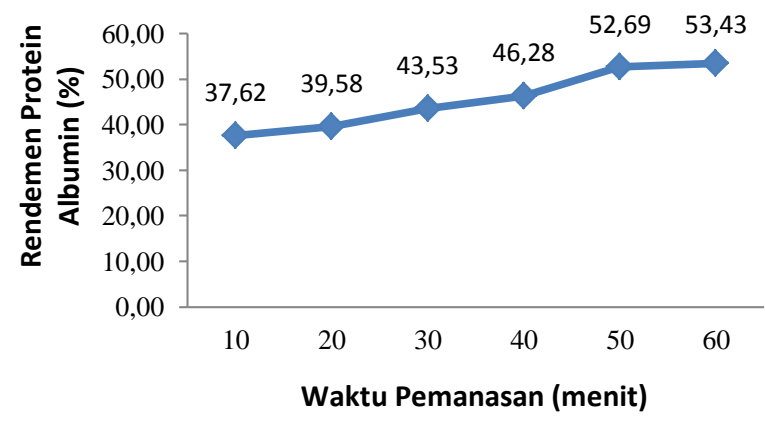

Gambar 2. Grafik hubungan antara waktu pemanasan dengan rendemen protein 
Dari Gambar 2 diketahui bahwa waktu pemanasan 60 menit menghasilkan rendemen protein tertinggi yaitu 53,43 \%. Hasil penelitian Askar (2005), rendemen protein yang dihasilkan dengan metode kontrol yaitu $64,36 \%$. Rendemen protein yang diperoleh belum maksimal diduga karena proses koagulasi protein belum mencapai titik optimum sehingga rasio getah biduri terhadap ekstrak protein ikan gabus masih dapat ditingkatkan lagi. Sedangkan hasil penelitian Suprayitno, dkk (2013), rendemen protein dengan metode pengendapan menggunakan ammonium sulfat yang dilanjutkan dengan pengeringan vakum yaitu $37,21 \%$. Hal ini menunjukkan bahwa metode ekstraksi secara enzimatik lebih optimum digunakan selain itu lebih aman karena tanpa penambahan bahan kimia. Adapun waktu pemanasan dari 10 menit sampai 50 menit terus mengalami peningkatan yang cepat namun pada waktu pemanasan 60 menit laju peningkatan berat endapan serta rendemen protein mulai berkurang sehingga persentasenya tidak berbeda jauh dengan waktu pemanasan 50 menit. Sehingga dapat disimpulkan bahwa waktu pemanasan optimum ekstrak protein pada 60 menit.

Menurut Witono (2007d), semakin besar konsentrasi enzim protease biduri dan semakin lama waktu hidrolisis maka kadar protein terlarut semakin tinggi. Semakin lama waktu hidrolisis, kontak enzim dengan substrat semakin lama, sehingga tingkat hidrolisis semakin tinggi dan dihasilkan molekul-molekul protein yang pendek sehingga kelarutannya meningkat. Sebagaimana juga dilaporkan oleh Hrckova, dkk (2002), bahwa jumlah asam amino bebas dari hidrolisis protein kedelai bebas lemak menggunakan protease selektif juga meningkat seiring dengan lamanya waktu inkubasi.

Adapun hasil uji statistik rendemen protein albumin ikan gabus yaitu nilai $F$ hitung 4322,5 dan $F$ tabel 0,01 dan 0,05 yaitu 4,39 dan 8,15 sehingga nilai $F$ hitung > F tabel 0,01 dan 0,05 (berbeda sangat nyata). Selain itu hasil Uji BNJ taraf $1 \%$ rendemen protein albumin ikan gabus yang menunjukkan angka yang diikuti huruf yang sama pada kolom yang sama, hasilnya pada perlakuan waktu pemanasan $10,20,30,40,50$ dan 60 menit berbeda nyata. Jadi, waktu pemanasan optimum yang menghasilkan rendemen protein albumin tertinggi yaitu pada waktu 60 menit dengan rendemen protein albumin sebesar $53,43 \%$.

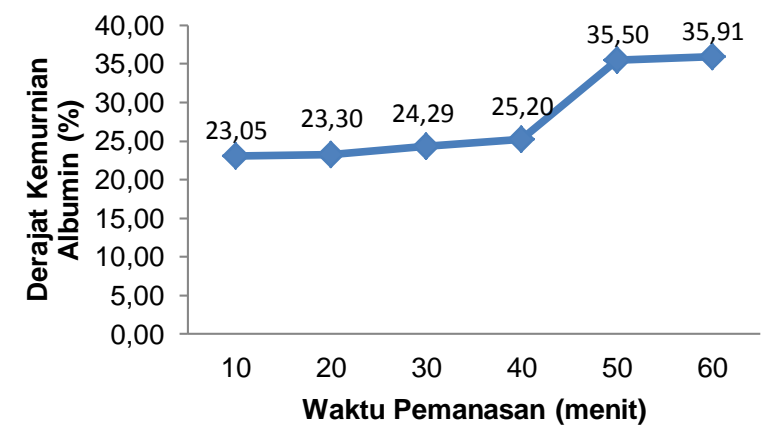

Gambar 3. Grafik hubungan antara waktu pemanasan dengan derajat kemurnian albumin ikan gabus.

Penentuan Derajat kemurnian albumin juga bergantung pada rasio getah biduri dan waktu pemanasan. Hubungan 
derajat kemurnian albumin dengan waktu pemanasan dapat dilihat pada Gambar 3.

Dari gambar 3 dapat diketahui bahwa pada waktu pemanasan 10 sampai 50 menit mengalami peningkatan sedangkan pada waktu pemanasan 50 sampai 60 menit laju peningkatannya berkurang sehingga derajat albumin yang dihasilkan tidak berbeda jauh persentasenya. Persen rendemen protein berbanding lurus dengan persen derajat kemurnian albumin, yaitu semakin meningkat persentasenya seiring dengan meningkatnya waktu pemanasan. Adapun derajat kemurnian albumin tertinggi diperoleh pada waktu pemanasan optimum 50 menit sebesar 35,50\%.

Hal ini dibuktikan dengan uji statistik pada analisis sidik ragam diperoleh nilai $F$ Hitung 1495,80 serta $F$ tabel 0,01 dan 0,05 sebesar 4,39 dan 8,15 sehingga terjadi perbedaan sangat nyata ( $F$ Hitung $>\mathrm{F}$ tabel). Dan dari hasil uji BNJ taraf $1 \%$ menunjukkan bahwa angka yang diikuti huruf yang sama pada kolom yang sama berbeda tidak nyata. Dimana pada waktu pemanasan 10 dan 20 menit berbeda nyata dengan waktu 30, 40,50, dan 60 menit namun tidak berbeda nyata dengan waktu 10 dan 20 menit. Pada waktu 30 menit berbeda nyata dengan waktu 10 , sampai 60 menit. Pada waktu 40 menit semua waktu berbeda nyata. Sedangkan pada waktu 50 dan 60 menit berbeda nyata dengan waktu $10,20,30$, dan 40 menit kecuali pada waktu 50 dan 60 menit berbeda tidak nyata. Sehingga waktu pemanasan optimum yang menghasilkan derajat kemurnian albumin tertinggi yaitu pada waktu 50 menit dengan derajat kemurnian albumin sebesar 35,50\%. Sedangkan hasil penelitian Suprayitno dkk (2013) dengan pengendapan menggunakan ammonium sulfat kadar albumin ikan gabus yang diperoleh yaitu sebesar 4,71 \%. Hal ini menunjukkan metode secara enzimatik menghasilkan kadar albumin yang lebih tinggi dan lebih aman dikomsumsi karena tanpa adanya penambahan zat kimia yang dapat bersifat racun bagi tubuh.

\section{KESIMPULAN}

Rendemen protein tertinggi dihasilkan pada rasio getah biduri 3,0 : 30 dan waktu pemanasan 60 menit yaitu sebesar $53,43 \%$. Derajat Kemurnian Albumin tertinggi dengan waktu pemanasan optimum dihasilkan pada waktu 50 menit yaitu sebesar $35,50 \%$.

\section{DAFTAR PUSTAKA}

Askar, I.S. 2005. Studi Pembuatan Konsentrat Ikan (Fish Protein Concentrate) dari Ikan Gabus. Jakarta: Epetani Deptan.

Carvallo, Y.N., 1998. Study Profit Asam Amino, Albumin, Mineral Zn pada Ikan Gabus (Ophiocephalus striatus) dan Ikan Tomang (Ophiocephalus micropeltus). Malang: Fakultas Perikanan. Universitas Brawijaya.

Day, R.A., Underwood, A.L. 2001. Analisis Kimia Kuantitatif, Edisi 6. Jakarta: Erlangga. hal 391

De Man. 1997. Kimia Makanan Edisi Kedua. Bandung: ITB press. 
Hrckova, M., Rusnakova M., Zemanovic J. 2002. Enzimatyc Hydrolysis of Defatted Soy Flour by Three Different Proteases and their Effect on the Functional Properties of Resulting Protein Hydrolysates. Czech J. food Sci. 20 (1): 7-14.

Nielsen, P.M. 1997. Food Proteins and Their Applications. NewYork: Marcel Dekker, Inc.

Poedjiadi, A. 1994. Dasar-dasar Biokimia. Jakarta: Universitas Indonesia.

Riyadi. 2009. Macam Spektrofotometri dan Perbedaannya (UV, Vis, dan Ir). Jakarta: Erlangga.

Rohman, Abdul. 2007. Kimia Farmasi Analisis. Yogyakarta: Pustaka Pelajar.

Suprayitno, E. 2008. Albumin Ikan Gabus Sebagai Makanan Fungsional Mengatasi Permasalahan Gizi Masa Depan. Malang: Fakultas Perikanan Universitas Brawijaya.

Suprayitno, E., Sulistiyati D.T., Yuniarti W.D., 2013. Pengaruh Suhu Pengeringan Vakum Terhadap Kualitas Serbuk Albumin Ikan Gabus (Ophiocephalus striatus). THPi Student Journal. 1(1) : 1-9.

Tandra, H.; Soemartono, H.W. dan A. Tjokroprawiro, 1988. Metabolisme dan Aspek Klinik Albumin. J. Med., 3: 249-258

Witono, Y., 2002a. Isolasi dan Karakterisasi Enzim Protease dari Getah Tanaman Biduri. Jurnal Teknologi Hasil Pertanian. 1(1): 114.

Witono, Y., 2002b. Pemanfaatan Enzim Protease dari Tanaman Biduri untuk Pengolahan Makanan.
Jurnal Sains dan Teknologi, 1(1): 32-37.

Witono, Y., Aulanni'am., Subagio, A., dan Widjanarko, S.B., 2007a. Telaah Teknologi Produksi Protease Secara Langsung dari Tanaman Biduri (Calotropis gigantea). Jurnal of Agrotechnologi.1(1): 816.

Witono, Y., Aulanni'am., Subagio, A., dan Widjanarko, S.B., 2007b. Presipitasi dari Getah Biduri (Calotropis Gigantea) Secara Salting Out Menggunakan Ammonium Sulfat. Journal of Agricultural Product Technologi. 7 (1): 20-26.

Witono, Y., Aulanni'am., Subagio, A., dan Widjanarko, S.B., 2007c. Purifikasi dan Karakterisasi Parsial Enzim Protease dari Getah Tanaman Biduri (Calotropis gigantea). Jurnal Teknologi dan Industri Pangan. 18(1): 1-9

Witono, Y., Aulanni'am., Subagio, A., dan Widjanarko, S.B., 2007d. Karakterisasi Hidrolisat Protein Kedelai Hasil Hidrolisis Menggunakan Protease dari Tanaman Biduri (Calotropis gigantea). Jurnal Penelitian Hayati. 13(1): 7-13. 